\title{
A Brief Survey of Water-land Dharma Service in Chinese Buddhism
}

\begin{abstract}
Yu Yuan ${ }^{1 *}$
${ }^{1}$ Shanghai Foreign Language School affiliated to SISU

*Corresponding author: Email: fz0944@shisu.edu.cn

ABSTRACT

Water-land Dharma Service, the grandest Buddhist ritual in Chinese Buddhism since implemented in Chinese monasteries, has been a manifestation of sinicization of Buddhism after it was introduced to China from India. Initiated by a Chinese Emperor Liangwu (464 C.E.-549 C.E), Water-land Dharma Service was well received and widely practiced in Song Dynasty (960 C.E.-1279 C.E). Not only was the whole ritual originality in Chinese Buddhism, but the scriptures in the service was written by Chinese Buddhist practitioners as well as great literates. Moreover, the whole display of the service is endowed with great artistic beauty both in its paintings peculiar to this service and the chanting with high musical appeal. This paper studies the Water-land Dharma Service from the historical perspective, and discusses its meanings, value and significance from the text of the ritual and from the interviews with the ritual practitioners, participants and scholars. These results shed light for the hidden powers of the rituals in the modern society.
\end{abstract}

Keywords: Buddhist ritual, Water-land Dharma Service, Chinese Buddhism

\section{INTRODUCTION}

Founded in ancient India 2000 years ago, Buddhism has spread to China taken its root and flourished in the vast land. As a religion that pins emphasizes on varied practices, Buddhism has experienced its transition of key practice in meditation to diversified practices as chanting, debating and discourse, in addition to meditation in Chinese Buddhism. Buddhist ritual, as a central element in modern monasteries, serves manifold purposes: (1) a unification of the whole Sangha, (2) a connection with the lay Buddhists and (3) a great contribution to the financial income of the monasteries. Among all the Buddhist rituals on the calendrical cycle, the Water-land Dharma Service ("Fajie Shengfan Shuilu Dazhai Pudu Shenghui") is undoubted the grandest one in terms of duration of time, variety of rituals and rites, number of practitioners and participants, as well as merits and artistic value. It is regarded as the most spectacular ceremony in which all enlightened and mundane beings of Land and water share a great feast for liberation.

\section{HISTORY OF THE WATER-LAND DHARMA SERVICE}

The whole ritual of Water-land Dharma Service had a long history of evolution. Since the original version compiled by Emperor Liangwu, it had undergone revisions and complements. Emperor Liangwu, as a pious Buddhist, dreamed of a monk one night that implied to him in the dream that it will bring greatest merit from benefit both the deities and the ghosts if hold the Water-land Dharma Service. The next day Emperor Liangwu consulted Buddhist monk Zhigong, and he followed the monk's advice and spent three years seeking for the relevant sources from the "Tripitaka" (the great sutras and sriptures). Finally the ritual text was compiled three years later, mainly based on Avatamsaka Sutra, Maharatnakuta Sutra, and the story and sutra of Ananda meeting the "Mianran" (FlamingMouth Sutra) [1].

However, as Stevenson points out that the shuilu owes little to the Flaming-Mouth Sutra in terms of the specific ritual content. With most Buddhist ritual genera in China, the shuilu and the fang yankou has reached its achievements not by sticking to any singular scriptural or traditional source, but by assembling of the liturgical 
forms drawn from a larger, extra textural field of ritual conventions. Thus, the combined rites have gone well beyond the root sutra [2].

The still existing version of the ritual was mainly compiled and adapted in the Song Dynasty consisting of the four parts: precepts, outline, text and tantrism. The people involved in the ritual majorly composed of masters to chant sutras and purity all the altars, masters to read the texts, and masters in charge of chanting (Fanbai), as well as the patrons to hold the hand stoves for burning incense and vow to pay tribute to the deities [3].

Based on the "Fozu tongji" (General History of Chinese Buddhism), the author Master Zhipan was invited to write the ten scrolls of "The New Scriptures of Shuilu" in the Southern Song Dynasty, which was later the basis of the versions by Master Lianchi in the Ming Dynasty. In the Qing Dynasty, Master Yirun following the version of Master Lianchi, and incorporated into four scrolls of the "Grand Ritual of Water-land Dharma Service", contributing to today's "Ritual of Shuilu" [3].

\section{CASE STUDY}

\subsection{Shanghai Jade Buddha Temple and the 2021 Qingming Water-land Dharma Service}

Located in China's metropolitan city Shanghai, Shanghai Jade Buddha Temple was built in the Qing Dynasty (1636 C.E. - 1912 C.E.). This temple is famous for its Jade Buddha statue, which could be dated back to 1882. At that time, Venerable Huigen, who was from the Putuo Mountain, brought five jade-made Buddha Shakyamuni statues from Myanmar and left two of them when he arrived in Shanghai subsequently. In 1882, local Buddhists built a thatched temple along the road to pay tribute to these two statues. Later, people rebuilt the Jade Buddha Temple in a new site in Shanghai, which is the current location of Anyuan Road in Putuo District [4]. In 2011, Fanbai (Buddhist chanting) of Shanghai Jade Buddha Temple was listed as the intangible Cultural Heritage. Every year, the Water-land Dharma Service attracts the greatest number of participants among all the religious venues in Shanghai mainly due to its grand scene (The temple has over 80 live-in monks) and its renowned Fanbai chanting.

In the 2021 Qingming Water-land Dharma Service held in Shanghai Jade Buddha Temple, based on the statistics provided by the temple, altogether 132 Huishou (the ones who have the privilege of entering the Inner Altar) participated in the ritual, while in the outer altars, the number of participants is hard to count, though the tablets for the outer altars amount to over 5,000 . The factual number of participants in the inner altar is around 80 averagely every day, mainly women and no more than 10 men participants.

\subsection{The layout of the altars of the Water-land Dharma Service}

As recorded in the ritual scriptures, this Qingming Water-land Dharma Service strictly laid out the altars based on the ritual format. Specifically, seven altars are set up in the ritual, which are the Inner Altar, the Grand Altar, Lotus Altar, Shurangama Altar, Varied Scriptures Altar, Avatamsaka Altar and Pure Land Altar. All the altars were laid out two days before the ritual except the Inner Altar, which initiated its ritual on the third day.

The Inner Altar is the core of the whole ritual, considered as the connection with the deities and the ghosts, though exclusive to the Huishou (The ones who pay the tablets to enter). Three statues of Pirojana Buddha, Sakyamuni Buddha and Amitabha Buddha are displayed in the center of the Inner Altar, and an altar table is set below, listing the offerings of fragrant lanterns and candles. In front of it set four rectangular tables, on which are laid bronze chime, drum, cymbal, hand bell and ritual scripts for the main masters who preside over the dharma service. The highlights in the Inner Altar are the Water-land paintings, which are only exhibited during the Water-land Dharma Service. These paintings represent the supernatural beings from different realms. Below the paintings are the tablets for these Buddhas, Bodhisattvas and ghosts. On the side walls are posted the tablets sponsored by the Huishou.

\subsection{The procedures of the Water-land Dharma Service}

In Shanghai Jade Buddha Temple, the seven-day long ritual mainly follows the following procedure. Primarily, there is a prelude called "Xuntan" (purifying the altars) to prepare for the ritual of the next day before the first day of the ritual. On the morning of the first day, monks and all participants free captive animals like pigeons or fish. Afterward, the seven altars initiate the ritual. On the second day, the seven altars continue chanting their respective sutras. On the third day, the Inner Altar has been established. After the completion of Jiejie (forming the enclosure of the altar), monks hang on sacred streamers and lotus lamps outside the Great Buddha's Hall to invite beings from the hell, the earthly world and the heaven, which is called Fafu Xuanfan. On the fourth day, The Inner Altar invites Shangtang (all deities and ancestors) to join in the ritual. On the fifth day, Xiatang (the ghosts in the hell) joins in the ritual. All ghosts have been invited in the ritual get Youmingjie (Ordination to the Spirits), i.e., they can be relieved. On the sixth day, Buddhists chant Dachanhuiwen (Eighty-eight Buddhas Repentance Scripture) is invited, which offer contribute to all 
deities, ghosts and people around all Dharma realm continues. The final Yankou (in addition to the ones on the second and the fourth night) is held on that night, which lasts about six hours continuously and is the climax of the whole ritual. On the seventh day, the last day of the Water-land Dharma Service, Buddhists see off all the paper images of gods and spirits on a papermade ship and burn the ship. This procedure is called Songsheng (farewell to the deities and ancestors)

As compared with both the Xuzangjing [5] and the chapter of "Ritual of Shuilu" compiled by Master Lianchi [6], the present-day "Ritual of Shuilu" [7] strictly sticks to the original versions in terms of the texts, the schedules of the ritual and lay out of the altars are also based on the ritual heritage. For example, all the three versions begin the text by "The day before the ritual, the masters should bathe and purify themselves."

\subsection{Interviews with ritual practitioners, participants and professionals of the Water- land Dharma Service}

Rituals do not just exist in texts, but they are performed and practiced. In this regard, to interview the people directly or indirectly associated with it may manifest the meanings and hidden powers from the perspective other than the texts and procedures. The followings are interviews with the ritual practitioners, participants and professionals.

INT (interviewer): As ritual participants, what impels you to take part in the seven-day long ritual? How does the ritual influence you?

PT (participant 1): (Mrs. Liu, lay Buddhist) Three years ago, my husband died. I suddenly felt that all her world collapsed. Then I went to the temple and attended the Water-land Dharma Service. The first time I took part in the ritual I had experienced great shock in it, especially in Yankou. I could even "heard" or "smell" the spirits. That feeling was so real that I could never forget. Later gradually I got over the sorrow of the loss, and my life returned to normal.

PT (participant 2): (Miss Luo, lay Buddhist): Young as I am, I was converted to Buddhism long time ago, and I take up Chan Buddhism to practice I also participated in Buddhist rituals quite often. The masters' chanting greatly impressed me, and I regard it as a supplement to my routine Chan meditation practices.

INT (interviewer): Water-land Dharma Service is quite complicated, so what does the grand ritual entail, what is your main duty in the ritual and what about the attraction of this ritual to lay Buddhists?

PRT (practitioner 1): (Ven. Wen Yuan, Weinuo (one of the eight senior masters) of Shanghai Jade Buddha Temple, Zhengbiao (leading chanting performer in the
Inner Altar) in the 2021 Qingming Water-land Dharma Service):

As the leading performer in the Inner Altar, which is the center of the whole ritual, I shoulder the duty my chanting mainly centers of communicating with the Ten Dharma Realms with my chanting. While I was chanting, I would also contemplate on these deities and express the texts on their behalf. My costumes, Pilum hat and the Dharma article or instrument in hand all help me to get involved in my role in the ritual.

I have been devoted to the Fanbai changing for three decade. I adopt the peculiar tone of its chanting manner, which has been handed from masters to masters for over a millennium, and during the chanting in the Water-land Dharma Service, that tone imparts peculiar aesthetic appreciation during the long-time rituals. I think that's why many participants come to the Water-land Dharma Service year after year. Apart from the merits they want to gain during the process, enjoyment the Fanbai chanting also contributes as a unique attraction.

INT (interviewer): The Water-land Dharma Service, which lasts for at least seven days and is condensed with varied rituals, is said to be the most powerful Buddhist ritual. Why should the temple hold such a solemn dharma service every year? What kind of merits could the participants or practitioners get from it?

PRT (practitioner 2): (Ven. Fa Xin, Sengzhi (one of the eight senior masters who is in charge of routines of Sangha and Buddhist rituals of Shanghai Jade Buddha Temple, Fubiao (second leading chanting performer in the Inner Altar) in the 2021 Qingming Water-land Dharma Service)

For Buddhists, to attend this dharma service on a yearly basis is beneficial to both the deceased ancestors and those alive. During the Water-land Dharma Service, all Buddha and Bodhisattvas from the varied dharma realms assemble to bless all sentient beings, including human beings, animals and even the ghosts. Such a holy union of the Buddha and Bodhisattvas is certain to provide the vast participants with incredible merits. The living people can make their ancestors rest in peace under the Buddhist masters' chanting, and in turn they gain their merit in this life.

It's also essential for the Buddhist monks to take part in the Water-land Dharma Service. As practitioners, we dip ourselves into varied sutras, scriptures and rites, and we chant and kowtow day and night, so that we can not only purify the venue of the ritual, but also purify our own heart.

INT (interviewer): Why does religion play an important role in the rite of passage of death?

PRO (professional): Dr. Tenzin Nambul, mentor in the Earl E. Bakken Center for Spirituality \& Healing, University of Minnesota) 
Religion plays significant roles in the passage of death in the following ways: Firstly, the ritual texts and procedures which have been handed down long time ago have proved to be powerful by the practice from varied experiences and numerous people. Moreover, the chanting and Dharma instrument contributed to the power. For the lay people, these religious instruments are considered as "sacred". For Buddhist practitioners, more than the sacredness of an object, it is your own mind. The Dharma instrument Vajra is the symbol of compassion, yet it means "emptiness" originally. Any single life is not existent on its own, and this is also true for human beings. Everything is based on our own behaviors and our connection with the rest of the world.

In the same sense, our deceased ancestors are also connected to us in some special means. Through these rituals between life and death, the living people may consider it as a bridge to "communicate" to deceased by writing their names on the tablets, and in turn they hope that after they die, their descendants may also offer them this kind of "treat", thus the fear of death (the greatest fear for humans lies in the unknown) has been alleviated after they attend the rituals.

\section{SIGNIFICANCE OF THE WATER- LAND DHARMA SERVICE}

From the Prelude to the "Ritual of Shuilu", Master Yinguang wrote, the Water-land Dharma Service is endowed with profound and long-lasting benefit by liberating the bad karma of the mundane beings. Besides, it gives impetus to the deities for them to advance to Buddhahood. All the ancestors would be paid tribute to, and all the living ones would be blessed [7].

Water-land Dharma Service, as the grandest Buddhist ritual that has been handed down for over 1,000 years of history, still serves as a revelation in the modern society. The significance mainly lies in the following aspects:

It promotes the spread of the religious belief. Religion, usually comprising of abstract norms or connects with supernatural beings, can hardly be easily comprehended by mundane people. However, it is essential for each religious belief to seek for its disciples and followers to transmit and spread it. Rituals, in this sense, serve as an ideal tool for this transmission. During and after the ritual, the participants have been immersed in the repetitive chanting of the sutras and scriptures. Additionally, they have to devote themselves to the whole procedures of Buddhist rituals, which are an inseparable part of the religion itself. When more and more Buddhist temples have the capability to hold the grand rituals, more and more people can participate in it, which contributes as a positive factor to the spread of Buddhism.
It is a manifestation of the cultural heritage. The Water-land Dharma Service incorporates numerous chanting scriptures, with the music and rhythm handed down orally by generations of Buddhist practitioners. In this regard, the Water-land Dharma Service can be considered as the living fossil to study Buddhist rituals from the historical and present-day perspectives. Though originally as a borrowed religious belief, Buddhism in modern Chinese society is permeated with Chinese cultural features, and Fanbai (Chinese Buddhist chanting) serves as one of its main characteristics. In the Water-land Dharma Services, Fanbai music rhythms are resonated in the whole temple, and all the participants or casual visitors can get access to the Chinese cultural heritage. Moreover, the scriptures of the ritual service are no lacking in literary aesthetics, e.g., the Zhaoqingwen (scriptures of invitation to the ghosts) in Yankou are so touching that several participants were witnessed as sobbing quietly after being moved by the scriptures when participating in the ritual.

From the perspective of the participants, they constantly kowtow during the ritual to pay tribute to the Buddha, Bodhisattvas and the Buddhist masters who preside over the ritual for 7 days. They also posted the ancestors' names on the tablets in the inner and outer altars for these souls and spirits to be liberated under the benefit of the Buddhist practitioner's chanting. Thus, the descendants of the deceased could be exempt from being pestered by their ancestor's spirits. All these are considered merits in Buddhism.

The significance of Water-land Dharma Service is beyond its financial returns. The ritual is also a close connection with the lay people. Usually, the Buddhist monasteries forbid the lay people to stay in it. However, the Huishou could get the privilege of staying in the temples during the Water-land Dharma Service, which have enough room to accommodate these participants. In this regard, every temple may form its core followers' circle, mainly consisting of the participants of the Water-land Dharma Service.

Meanwhile, Buddhist rituals are not without their limitations. Just as some scholars as Xue $\mathrm{Yu}$ put forward, most monasteries nowadays focus too much on the rituals as well as the financial returns of it. On this basis, it may lead to some negative outcomes, e.g., the fatigue of the Buddhist monks makes them unable to concentrate on their own routine Buddhist practices. In his idea, only those Buddhist monks whose deeds and behaviours live up to the Buddha's teachings may be worthy of the offering [8]. In addition, the frequent rituals in Buddhist temples may give the lay Buddhists and the disciples a delusion that temples are the venue peculiar to rituals that mainly deal with the death. Besides, it may also obstruct the development of the modern monasteries by confining themselves to the specialty of ritual ceremonies rather than a venue for 
practicing Buddhism through different means, e.g., meditation, copying the Buddhist sutras and appreciating Buddhist art.

\section{CONCLUSION}

In summary, the Water-land Dharma Service, the grandest ritual in the religion of Buddhism is endowed with rich historic and present-day significance. Aside from the merits that the participants consider they may make, the ritual itself can enhance people's belief in Buddhism and serve as an inheritance of the cultural heritage, both in the ritual texts, practices and the aesthetic perspective, e.g. the Shuilu paintings and Fanbai chanting. All these contribute to the unparalleled status of the Water-land Dharma Service among all the rituals in Buddhism. At the same time, the hidden powers of the ritual can be manifested in that it can purify the heart and soul of both the participants and practitioners; it can also mould people's attitude to life and death and alleviate or even eliminate people's fear of death. These results offer a guideline for Buddhist rituals in modern society in their inheritance of cultural heritage, the financial support for the temples, and the appeal to the lay Buddhists, all of which serve great purposes for the development and prosperity of this ancient religious belief.

\section{REFERENCES}

[1] C. Hou, Shanghai Buddhism (2020) p22.

[2] Stevenson, Daniel B., Text, Image, and Transformation in the History of Shuilu fahui, the Buddhist Rite for Deliverance of Creatures of Water and Land, Cultural Intersections in Later Chinese Buddhism. Honolulu: University of Hawaii Press, 2001.

[3] C.Hou, Shanghai Buddhism (2020) p24.

[4] Y. Zhao, Three Prominent Temples in Shanghai. Zhongzhou Archives Publishing House, 2014

[5] Xuzangjing, Xinwenfeng Press,1995, Volume 129, p527-699

[6] L. C. Shi. The Complete Works of Master Lianchi (the Second Volume), Shanghai Ancient Books Publishing House, 2011

[7] Ritual of Shuilu, Shanghai Buddhism Press, 2002

[8] Y. Xue. Merit Transfer and Life after Death in Buddhism. Christian Study Centre on Chinese Religion and Culture, 2003 